\title{
Energy balances in man
}

\section{By R. PAssmore, Department of Physiology, University of Edinburgh}

The same fundamental physiological principles are involved in studies on the energy balance in man as in animals. In consequence almost all that Dr Blaxter has told us already is relevant to human studies. In one respect experiments on man are easier than those on ruminants. Very little gas is produced by fermentation in the human alimentary canal. A healthy person will pass up to I 1 . of flatus daily (Fries, I 906; Alstead \& Patterson, r948). The amount of methane formed is so small that it can be neglected in drawing up human energy balances. This is a great saving of labour. On the other hand the calorimeter chambers at the Hannah Research Institute and the Rowett Research Institute would not in their present forms be socially acceptable to most human subjects. To provide such chambers with the comfort and amenities of a modest hotel bedroom would be very expensive. There are no human calorimeter chambers in Great Britain and very little work has been done with them since the classical experiments of Atwater and his colleagues in the last decade of the igth century.

Table I. The energy exchanges in a man leading a sedentary life in a calorimeter chamber

(All figures are $\mathrm{kcal} / 24 \mathrm{~h}$ from continuous measurements over 4 days)

Credit

Heat of combustion of food

Heat due to temperature of food

Estimated heat of combustion of tissue protein lost*

$\begin{aligned} 2717 & \text { Measured heat output } \\ 53 & \text { Equivalent heat of water vaporized } \\ & \text { Heat of combustion of faeces } \\ \text { 2I } & \begin{array}{l}\text { Heat of combustion of urine } \\ \text { Estimated heat of combustion of tissue } \\ \text { fat gained } \dagger\end{array} \\ \text { 279 } & \end{aligned}$

Measured heat output

I817

544

142

149

I 7 I

2823

*From $\mathrm{N}$ balance. $\uparrow$ From $\mathrm{C}$ balance.

(Atwater \& Benedict, I899).

Every year I have the pleasure of describing Atwater's beautiful experiments to a new class of medical students. They will never become commonplace and no apology is needed for presenting a summary of one of his studies to a learned society. Table I shows that it is possible to make measurements on a human subject over a period of several days with the precision customary in the physical sciences. In this study Atwater showed that the energy expenditure balances the net energy intake and the energy equivalent of the change in body composition over a 4-day period within $30 \mathrm{kcal} /$ day or about $\mathrm{I} \%$ of the total exchanges. He was also able to show that energy output measured as heat (direct calorimetry) correlated well with the energy output calculated from measurements of oxygen consumption (indirect calorimetry). In the last 20 years there have been great improvements in the methods of measuring oxygen consumption by man over long periods and under field conditions. These have 
led to a fresh interest in the study of human energy balances and it is these with which I shall be concerned. The human energy balance can be written:

$$
\begin{aligned}
\text { Calorie intake }= & \begin{array}{l}
\text { Calorie output } \\
\text { (dietary) } \\
\\
\\
\\
+ \text { (resting metabolism }
\end{array} \pm \Delta \text { body calories activity) }
\end{aligned}
$$

Each component will now be considered separately.

\section{The calorie intake}

In studies in a metabolic ward, it is possible for a dietitian to weigh out a duplicate portion of the subject's diet, which can then be homogenized and dried, and the calorie content determined with a bomb calorimeter. Similarly the calorie content of the urine and faeces can be directly determined. This is exactly the procedure followed by Atwater. It is very difficult to state the size of the errors involved. With careful techniques they are certainly small. In Professor Strong's metabolic ward in the Western General Hospital at Edinburgh, there is good reason to think that the estimates of net calorie intake are correct within $\pm 2 \%$.

Not all calorie balance studies can be carried out in a metabolic ward and field conditions inevitably involve loss of accuracy. It is usually inconvenient and difficult to collect faeces. In the absence of diarrhoea, the faecal calories may vary from 3 to $8 \%$ of the gross dietary calories. If it is not practical to collect the faeces and to analyse a duplicate sample of the food eaten, then tables of food analyses must be used. For subjects living and feeding in a laboratory or hostel a dietitian should be able to provide a simple but varied and attractive diet, whose net calorie value can be calculated from food tables with an accuracy between \pm 5 to $10 \%$ and probably nearer $\pm 5 \%$. The largest important errors are likely to arise from inadequate supervision of the subjects, leading to a failure to eat all the food provided or to the consumption of unrecorded extras.

If the subject is eating his normal diet either at home or in a hostel, the error will be greater. He is likely to eat a variety of made-up dishes, whose composition is not precisely known, and the error from the use of food tables is consequently liable to be greater. The difficulties in weighing and recording all the food are also great, even with a conscientious subject. There is an immense literature on the reliability of dietary surveys and it is very difficult to assess the accuracy of the results in any one individual. In my opinion the error in assessing the calorie intake is unlikely to be less than $\pm 10 \%$ and often much greater.

\section{The calorie output}

The estimation of the daily energy expenditure involves the recording of the time spent in each of the subject's daily activities and the assessment of the metabolic cost of each activity.

Then

calorie output $=\Sigma$ time spent in each activity $\times$ metabolic cost of the activity. 
The accurate recording of how the subject spends every minute of the 24 hours is difficult. Clearly this is more easily done if the subject is living an ordered life with a limited number of activities, either in the metabolic ward of a hospital or in a research laboratory. Next the metabolic cost of each activity has to be determined by indirect calorimetry or assessed from tables (Passmore \& Durnin, r955; Durnin $\&$ Passmore, 1967). Table 2 gives an example of the measurement of the calorie output by a young woman over a 5 -day period spent in a metabolic ward and provided with a diet aimed to meet her requirements.

Table 2. The energy exchanges in an obese lady, height $167 \mathrm{~cm}$, weight $92 \mathrm{~kg}$, living in a metabolic ward of a hospital and taking moderate exercises

(All figures are $\mathrm{kcal} / 24 \mathrm{~h}$ from records over 5 days)

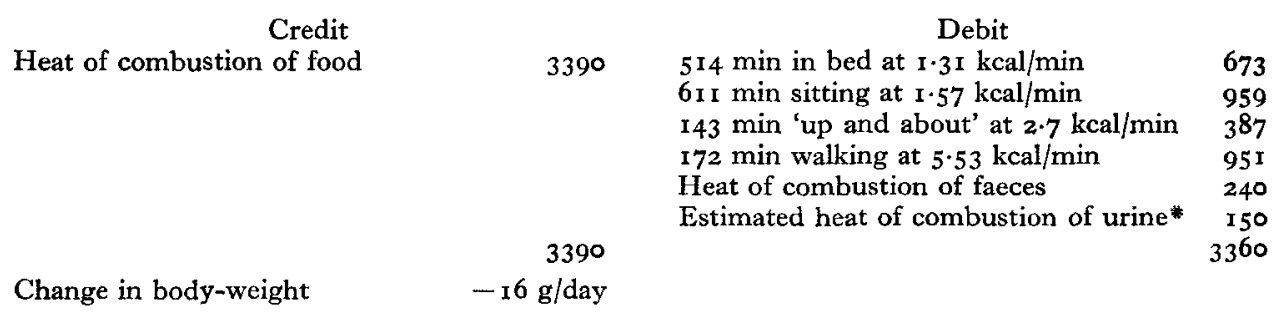

*Calculated by multiplying the urinary $N$ by $7 \cdot 9$.

(Passmore, Strong, Swindells \& el Din, r963).

The estimate of the calorie output balances the estimate of the calorie intake within $30 \mathrm{kcal} /$ day or $\mathrm{I} \%$. I would not pretend that we can always get as good agreement between the two estimates during a control period. However if they differed by as much as $150 \mathrm{kcal} /$ day or $5 \%$, with a negligible change in body-weight, we would overhaul techniques and especially the supervision of the patient. With improved methods of indirect calorimetry, allowing continuous recording of $\mathrm{O}_{2}$ consumption and $\mathrm{CO}_{2}$ output for long periods, as with the Kipp and Zonen diapherometer, it should be possible to estimate daily energy expenditure consistently with an error of no more than $2-3 \%$.

There have been numerous studies, when both the dietary calories and the energy expenditure have been measured under field conditions on subjects carrying on with their normal work and recreations (Durnin, 196I; Harries, Hobson \& Hollingsworth, I962). Usually over a week energy output balances energy intake within $\pm 10-20 \%$. The accuracy of such estimates depends on how varied the activities of the subject are and how reliable he and the observers are in recording these activities. Under the best possible circumstances, I do not think that an estimate of daily energy expenditure made on a subject under field conditions could be expected to have an error of less than $\pm 10 \%$.

\section{Change in body calories}

Fat. There are now several ways of obtaining an indirect measure of the total body fat in living man. One of the most sophisticated and perhaps the most accurate is 
the use of an isotope of krypton $\left({ }^{85} \mathrm{Kr}\right)$ as a fat marker. Hytten, Taylor \& Taggart (1966) report measurements of total body fat derived from ${ }^{85} \mathrm{Kr}$ studies, in which values obtained on the same subject within a few days usually agreed within $\mathbf{I} \mathrm{kg}$ of each other. However, in some instances the differences were greater, the highest being $1.9 \mathrm{~kg}$. In my experience underwater weighing, which is a much simpler and so more frequently used method for assessing body fat, does not give results which are so closely repeatable. If we assume, as seems reasonable, that it is impossible with the techniques at present available to measure body fat in man with an accuracy greater than $\mathrm{I} \mathrm{kg}$, it follows that we cannot detect a change in body calories of less than $\pm 9000 \mathrm{kcal}$. Measurements of body fat are therefore quite useless in energy balance studies in man, unless the calorie imbalance is large, probably of the order of $20000 \mathrm{kcal}$. This means in practice that the study must be continued over at least 4 weeks. Underwater weighing and other methods of assessing total body fat are, of course, useful in determining the changes in body composition over longer periods as in athletes who are training vigorously (Pařizková, I966).

Carbohydrate. It is often assumed that the store of glycogen in the muscles and liver is small and comparatively fixed. Passmore, Strong, Swindells \& el Din ( $9_{963}$ ) reported experiments on overfeeding in which the measurements of the respiratory quotient indicated that the glycogen store could be increased by as much as $\mathrm{I} \mathbf{k g}$. We hope to present to the Society soon further experiments confirming this finding. Biopsy studies on man have shown that there can be large variations in the glycogen content of muscle with values up to $5 \mathrm{~g} / 100 \mathrm{~g}$. As an adult human body contains about $30 \mathrm{~kg}$ of muscle, there is a large potential store here.

There is no method available for determining the total carbohydrate content of man.

Protein. Changes in total body protein cannot be measured directly, but can be derived from measurements of the nitrogen balance with all their cumulative errors (Owen, 1967). A negative or positive calorie balance is almost always associated with a negative or positive nitrogen balance, which may be large. Thus an undernourished African is reported to have been in positive nitrogen balance equivalent to a gain of $3 \mathrm{~kg}$ of protein, during a period of nutritional rehabilitation lasting 77 days (Holmes, Darke, Greaves \& Read, 1962). The protein laid down by this man involved a gain in body energy of over I $5000 \mathrm{kcal}$. Yet his weight did not increase over this period.

Change in body-weight. So far no mention has been made of changes in bodyweight as an aid to deriving change in body calories. A change in body calories must be accompanied by a corresponding change in body solids. However this is often obscured by changes in total body water. A sudden reduction in the calorie intake is almost always accompanied by a rapid loss of body water which may amount to $4 \mathrm{~kg}$ (Passmore, 1961). The changes in body water associated with an excess calorie intake are not well defined.

The total body water is not precisely regulated in man. There are commonly variations up to $\pm \mathbf{I} \mathrm{kg}$ from day to day and occasionally as much as $2 \mathrm{~kg}$. These are, of course, most easily observed as daily variations in body-weight. A gain or loss in body-weight of $2 \mathrm{~kg}$ might be due to a gain or loss of body fat and involve a disturb- 
ance of the energy balance by as much as \pm 18 ooo kcal, or it might be due to a gain or loss in body water, whilst the subject remained in energy balance. There is no simple way of measuring in man the changes in body composition associated with small changes in weight. These considerations indicate how dangerous it is to draw conclusions about the energy balance from small changes in body-weight.

\section{Discussion}

The body-weight and with it the energy reserve is controlled by balancing the dietary energy intake against the energy output in physical activities and in resting metabolism. A lean man may have no more than $3 \mathrm{~kg}$ of body fat and a plump woman as much as $25 \mathrm{~kg}$ without either being abnormal or in any way unhealthy. In the one, daily energy exchanges may amount to as much as $10 \%$ of the total energy reserve and in the other to less than $\mathrm{r} \%$. Yet in both the energy balance may be well maintained and body-weight remain constant over many years. How this balance is maintained and its relation to the size of the energy reserve is a proper subject for physiological study. We know a good deal about the immediate responses to a period of negative calorie balance, but as much less about how the body reacts to a positive calorie balance, brought about either by increased food intake or diminished physical activity.

Field studies in which neither dietary intake nor the physical activities of the subject can be controlled or measured with precision by the investigator are liable to so great an error that they are not likely to throw much light on the nature of the controls, which are very precise over a period of time. As Atwater showed, it is possible to measure the energy exchanges of man with great accuracy. Indeed in many respects man is a better experimental animal than rats or other animals commonly used by nutritionists. Direct calorimetry is both expensive and technically difficult; it also involves restrictions on the subject, which would become intolerable after a few days. Indirect calorimetry is both cheaper and easier and it is possible to study a subject over many weeks. As this paper attempts to show, it needs to be only a little less accurate than direct calorimetry. Such accuracy is not compatible with the freedom of a normal life; it can only be achieved if the subject is under the strict discipline that is possible when living in the metabolic ward of a hospital or in a well-equipped research laboratory.

\section{REFERENCES}

Alstead, S. \& Patterson, J. F. (1948). Lancet, i, 437.

Atwater, W. O. \& Benedict, F. G. (1899). Bull. U.S. Dep. Agric. no. 69.

Durnin, J. V. G. A. (1961). F. Physiol., Lond. 156, 294.

Durnin, J. V. G. A. \& Passmore, R. (1967). Energy, Work and Leisure. London: Heinemann.

Fries, J. A. (1906). Am. \%. Physiol. r6, 468.

Harries, J. M., Hobson, E. A. \& Hollingsworth, D. F. (1962). Proc. Nutr. Soc. $21,157$.

Holmes, E. G., Darke, S. J., Greaves, J. P. \& Read, W. W. C. (1962). Q. fl exp. Physiol. 47, 5.

Hytten, F. E., Taylor, K. \& Taggart, N. (1966). Clin. Sci. 3x, I I1.

Owen, E. C. (1967). Proc. Nutr. Soc. 26, 19.

Parizková, J. (1966). Proc. Nutr. Soc. 25, 93.

Passmore, R. (1961). Nutr. Dieta, 3, I.

Passmore, R. \& Durnin, J. V. G. A. (1955). Physiol. Rev. 35, 8or.

Passmore, R., Strong, J. A., Swindells, Y. E. \& el Din, N. (1963). Br. F. Nutr. 17, 373. 